\title{
ЦИТОТОКСИЧНОСТЬ КОНЬЮГАТОВ ДАУНОРУБИЦИНА С СЕСКВИТЕРПЕНОВЫМИ ЛАКТОНАМИ В ОТНОШЕНИИ РЕЗИСТЕНТНОЙ ЛИНИИ КЛЕТОК А549/DNR
}

\author{
Л.В. Аникина, А.В. Семаков, С.А. Пухов, А.А. Глоба, С.В. Афанасьева, \\ С.Г. Клочков
}

Лаборатория природных соединений, Институт физиологически активных веществ РАН, 142432, РФ, Черноголовка, Северный проезд, 1.

DOI: 10.19163/MedChemRussia2021-2021-290

E-mail: anikina1970@gmail.com

Антрациклиновые антибиотики как противоопухолевые агенты остаются препаратами первой линии при лечении гемобластозов, рака молочной железы и легкого, сарком мягких тканей, несмотря на значительные органотоксические побочные эффекты и развитие лекарственной устойчивости к ним опухолей. Для преодоления лекарственной устойчивости активно синтезируются производные антрациклиновых антибиотиков с природными соединениями различных классов [1,2]. Нами были синтезированы конъюгаты даунорубицина с сесквитерпеновыми лактонами по 3'-аминогруппе антрациклина с эпоксиизоалантолактоном (LO4-DNR), дегидрокостуслактоном (SL62-DNR), и рейнозином (SL73-DNR).

Резистентный к даунорубицину фенотип клеток A549 (A549/DNR) был получен в нашей лаборатории из родительской линии клеток A549 (карцинома легкого, ATCC ${ }^{\circledR}$ CCL-185 19 ) путем длительного культивирования клеток с возрастающими концентрациям (от 5 до 400 нМ) даунорубицина. Для эксперимента обе линии - родительскую A549 и резистентную A549/DNR - параллельно подвергали воздействию DNR, L04-DNR, SL62-DNR, SL73-DNR в диапазоне доз от 10 до 0,01 $\mu$ М в течение 72 часов, после чего определяли цитотоксичность в МТТ-тесте с вычислением $\mathrm{IC}_{50}$.

Результаты исследований свидетельствуют о том, что культивируемая при 0,4 мкМ даунорубицина линия клеток A549/DNR приобрела к нему резистентность, значения $\mathrm{IC}_{50}$ по отношению к даунорубицину выросли в 10 раз. Конъюгаты дегидрокостуслактона SL62-DNR и рейнозина SL73-DNR с даунорубицином оказались менее эффективны в отношении этой линии, - в 10 раз и в 17 раз соответственно, и только конъюгат с эпоксиизоалантолактоном L04-DNR снизил свою активность всего в 5 раз. В дальнейшем планируется провести исследование кинетики взаимодействия L04-DNR с резистентной опухолевой линией клеток A549/DNR - захват, накопление, выброс - по сравнению с исходным даунорубицином.

\section{Литература}

[1] A.V. Semakov, L.V. Anikina et al, Russian Journal of Bioorganic Chemistry. 2018, 44, 538-546

[2] L.V. Anikina, A.V. Semakov et al, Pharmaceutical Chemistry Journal. 2018, 52, 308-311 